\title{
PENGARUH FAKTOR PENDIDIKAN REMAJA DAN EKONOMI KELUARGA DENGAN SIKAP UNTUK MEMUTUSKAN MENIKAH DI USIA MUDA DI DESA PRAPAG KIDUL LOSARI BREBES
}

\author{
Maemunah dan Abi Muhlisin \\ Prodi Keperawatan Fakultas Ilmu Kesehatan \\ Universitas Muhammadiyah Surakarta \\ Jl. A Yani, Tromol Pos I, Pabelan, Surakarta
}

\begin{abstract}
Young age marriage may give negative impact if it is happened without age and phsycosocial maturity. The negative impacts that may be occured were the increase of divorce cases, broken school, the risk of mother mortality rate, risk of cancer cervic, and also the risk of infant mortality rate. This research was descriptive correlational with retrospective approach. The number of respondents were 50 people in Prapag Kidul, Losari, Brebes. Data of economic and educational level and attitude to decide marriage in young age were obtained using questionarre. The Pearson Product Moment was used to determine the correlation between those variables. Result of this research showed that young age marriage was majority happened in teenagers with low level of education, low level of parent's education, and low level of economic status.
\end{abstract}

Keywords: Education Level, Economic Level, Attitude, Young Age Marriage

\section{PENDAHULUAN}

Fenomena kawin muda saat ini tampaknya merupakan "mode" yang terulang. Dahulu, kawin muda dianggap lumrah tetapi dengan bergantinya tahun, makin banyak yang menentang perkawinan di usia dini. Sekarang fenomena tersebut kembali lagi, kalau dulu orang tua ingin anaknya menikah muda dengan berbagai alasan, maka kini malah banyak remaja sendiri yang bercita-cita kawin muda. Mereka bukan saja remaja desa, melainkan juga remaja-remaja di kota besar.

Data-data menunjukkan bahwa pernikahan dini juga menjadi kecenderungan di berbagai negara berkembang. Setidaknya setengah perempuan muda di negara Afrika Sub-Sahara, mulai menikah sebelum usia 18 tahun. Sementara di kawasan Asia, sebanyak 73\% perempuan di Bangladesh menikah sebelum usia 18, dibandingkan dengan 14\% di Filipina dan Sri Langka, sedangkan di Cina hanya 5\%. Para wanita di negara maju tidak mungkin menikah sebelum usia 18; walaupun di Prancis, Inggris dan Amerika Serikat sebanyak 10-11\% melakukannya, namun di Jerman dan di Polandia 
hanya 3-4\% wanita muda melakukannya. Sementara di Indonesia pernikahan dini 15-20\% dilakukan oleh pasangan baru. Biasanya, pernikahan dini dilakukan pada pasangan usia muda yang rata-rata umurnya antara 18,19 , dan 20 tahun. Secara nasional, pernikahan dini dengan usia pengantin di bawah usia 16 tahun sebanyak $26,9 \%$ (Hertog, 2006).

Penelitian yang dilakukan Ikatan Sosiologi Indonesia (ISI) Jawa Barat mengungkapkan fakta masih tingginya kawin muda di Pulau Jawa dan Bali. Di antara daerah-daerah tersebut, Jawa Barat menduduki peringkat pertama dalam jumlah pasangan yang melakukan kawin muda. Dari data media umur kawin pertama di Pulau Jawa pada 2002-2003, usia kawin di Jawa Tengah menempati peringkat kedua yaitu 18,8 tahun (Hertog, 2006).

Anggapan remaja desa lebih memungkinkan untuk menikah diusia muda karena menurut hasil penelitaan Subiyantoro (2002) Bahwa perempuan dalam pernikahan didasarkan pada mitos "Perawan Tua" persoalan mendasar dari seorang anak perempuan, ketika dia telah memasuki usia dewasa, banyak orang tua menginginkan anaknya untuk tidak menjadi perawan tua. Menjadi perawan tua bagi kebanyakan masyarakat dianggap sebagai bentuk kekuranmgan yang terjadi pada diri perempuan. Untuk itu, dalam bayangan ketakutan yang tidak beralasan banyak orang tua yang menikahkan anaknya pada usia muda. Kondisi itulah yang menjadikan timbulnya persepsi bahwa remaja desa akan lebih dulu menikah dari pada remaja kota.

Menurut Dadang (2005), banyak kasus perceraian merupakan dampak dari mudanya usia pasangan bercerai ketika memutuskan untuk menikah. "Kebanyakan yang gagal itu karena kawin muda". Dalam alasan perceraian tentu saja bukan karena alasan kawin muda, melainkan alasan ekonomi dan lain sebagainya. Tetapi masalah tersebut tentu saja sebagai salah satu dampak dari perkawinan yang dilakukan tanpa kematangan usia dan psikologis.

Menurut Nugroho (2006) perempuan yang menikah dibawah umur 20 tahun beresiko terkena kanker leher rahim. Pada usia remaja, sel-sel leher rahim belum matang. Kalau terpapar human papiloma virus atau HPV pertumbuhan sel akan menyimpang menjadi kanker.

Pernikahan usia dini juga menyebabkan resiko kematian ibu dan anak, karena organ biologis peempuan dibawah usia 20 tahun belum siap secara penuh untuk melahirkan. Bayi yang dilahirkannya jika tidak meninggal, bayi lahir prematur atau cacat (Teguh, 2007).

Pernikahan usia muda akan berdampak pada kualitas anak, keluarga, keharmonisan keluarga dan perceraian. Karena pada usia tersebut, ego remaja masih tinggi, rata-rata pernikahan usia muda ini terjadi di daerah 
pantai utara, pantai selatan dan di pegunungan. Penyebabnya karena faktor sosial budaya, ekonomi, pendidikan dan agama (Suryadi, 2005).

Dari studi pendahuluan di Desa Prapag Kidul pada Desember 2010, Kecamatan Losari, Kabupaten Brebes, diperoleh data jumlah penduduk total di Desa Prapag Kidul sebanyak 11.589 jiwa dengan jumlah penduduk lakilaki 5.675 jiwa dan jumlah penduduk perempuan 5.915. Jumlah penduduk remaja di Desa Prapag Kidul adalah sebanyak 1110 jiwa yaitu penduduk remaja putra sebanyak 541 jiwa (48,7\%) dan penduduk remaja putri sebanyak 569 jiwa (51,3\%). Sedangkan data terkini yang di peroleh untuk remaja yang menikah di usia muda sebanyak 50 orang, di Desa rapag Kidul rata-rata menikah pertahun sebanyak 25 orang. Menurut Kepala desa Prapag Kidul Bp. H. Shokin, remaja menikah usia muda di Desa Porapag Kidul masih tergolong tinggi. Penduduk Desa Prapag Kidul sebagian besar bermata pencaharian sebagai petani sawah, nelayan, petani tambak.

Dilihat dari aspek pendidikan, remaja di Desa Prapag Kidul mayoritas lulusan Sekolah Dasar (SD) dan Sekolah Menengah Pertama (SMP). Kebanyakan dari mereka tidak melanjutkan ke jenjang pendidikan yang lebih tinggi, dikarenakan terbentur dengan masalah ekonomi dan tingkat pendidikan ratarata orang tua mereka juga rendah, sehingga kurang mendukung anak dalam melanjutkan pendidikan ke jenjang yang lebih tinggi. Mayoritas remaja di Kecamatan Losari yang terdiri dari 22 desa, hanya berpendidikan SD dan SMP saja, masih sedikit dari mereka yang melanjutkan pendidikan tingkat SMA. Apalagi remaja di desa Prapag Kidul, banyak remaja yang putus sekolah SD dan SMP saja. Hanya sebagian kecil dari remaja di Desa Prapag Kidul yang melanjutkan ke tingkat SMA, hanya kira-kira 12,6 \% dari jumlah remaja di desa Prapag Kidul. Sehingga desa Prapag Kidul merupakan salah satu desa yang memiliki jumlah remaja nikah muda tinggi di Kecamatan Losari.

Tujuan penelitian ini adalah Untuk mengetahui pengaruh faktor pendidikan remaja dan ekonomi keluarga dengan sikap remaja untuk memutuskan menikah di usia muda di desa Prapag Kidul, Kecamatan Losari, Kabupaten Brebes.

\section{METODE PENELITIAN}

Jenis penelitian ini adalah deskriptif koreltif dengan mengggunakan metode survey retrospektif. Subyek dalam penelitian ini adalah remaja yang sudah marriage di Desa Prapag Kidul, kecamatan Losari, kabupaten Brebes sebanyak 50 orang.

\section{A. Definisi Operasional}

Pendidikan adalah Pendidikan formal yang pernah ditempuh oleh responden. Alat ukur: kuesioner 
dengan 3 pertanyaan dengan kategori: Tidak Lulus SD, SD/MI, SMP/MTs, SMA/Aliyah, PT/Sarjana. Skala ordinal. Ekonomi adalah Penilaian suatu kondisi penghasilan ekonomi keluarga perbulan. Alat ukur: kuesioner dengan 2 pertanyaan dengan kategori: Rendah: < Rp. 500.000,-, Menengah; Rp. 500.000,-s/dRp. 1.000.000,-, Tinggi: > Rp. 1.000.000,Skala ordinal.

Sikap remaja untuk memutuskan marriage muda adalah Suatu respon remaja untuk memilih membina rumah tangga di usia muda Alat ukur : kuesioner dengan 14 pertanyaan dengan kategori : baik, cukup, kurang. Skala ordinal.

\section{B. Uji Validitas dan Reliabilitas Kuesioner}

Validitas adalah suatu ukuran yang menunjukan tingkat-tingkat kevalidan atau keshahihan suatu instrumen. Sebuah instrument dikatakan valid apabila mampu mengukur apa yang diinginkan (Arikunto, 2002). Rumus korelasi yang digunakan adalah korelasi product moment dari pearson. Reliabilitas alat ukur penelitian ini diuji realibilitas dengan rumus Alpha.Cronbach.

\section{Pengolahan dan Analisis Data Penelitian}

Pengolahan data meliputi: Editing, coding, entry, tabulating. sedangkan uji statistik yang digunakan adalah uji statistik Spearman Rho. Uji ini dipakai karena skala data yang dikumpulkan berbentuk ordinal. Karena $\mathrm{N}$ lebih dari 30, dimana tabel tidak ada, sehingga untuk menguji signifikansi hubungan antara variabel bebas dengan variabel terikat menggunakan uji signifikansi yaitu uji $t$, kemudian nilai $t_{\text {hitung }}$ dibandingkan dengan nilai $t_{\text {tabel }}$ pada derajat signifikansi $5 \%$, dengan $\mathrm{N}=50$. Jika nilai $\mathrm{t}_{\text {hitung }}$ lebih besar dari $\mathrm{t}_{\text {tabel }}$ maka $\mathrm{H}_{0}$ ditolak dan $\mathrm{H}_{\mathrm{a}}$ diterima, sebaliknya jika nilai $t_{\text {hitung }}$ lebih kecil dari $t_{\text {tabel }}$ maka $\mathrm{H}_{0}$ diterima dan $\mathrm{H}_{\mathrm{a}}$ - ditolak.

\section{HASIL DAN PEMBAHASAN}

\section{A. Karakteristik Subyek Penelitian}

Subyek dalam penelitian ini adalah seluruh remaja yang menikah di usia muda, bertempat tinggal di Desa Prapag Kidul Kecamatan Losari Kabupaten Brebes dengan kriteria tertentu. Jumlah responden laki-laki 19 orang dan untuk responden perempuan 31 orang, keduanya saat marriage berusia 14 -19 tahun. Responden saat ini berusia 15 - 21 tahun. Pendidikan mereka mulai tidak tamat SD sampai SMA. Selanjutnya untuk mengetahui proporsi responden menurut karakteristiknya, ditampilkan sebagai berikut. Diskripsi tingkat pendidikan orang tua responden disajikan pada Tabel. 1.Sedangkan tingkat pendidikan responden disajikan pada Tabel. 2 . 
Tabel 1. Tingkat Pendidikan Orang Tua Responden

\begin{tabular}{cccccc}
\hline \multirow{2}{*}{ No } & \multirow{2}{*}{ Tingkat Pendidikan } & \multicolumn{2}{c}{ Ibu } & \multicolumn{2}{c}{ Bapak } \\
\cline { 3 - 6 } & & Jumlah & $\mathbf{0}$ & Jumlah & \% \\
\hline 1. & Tidak Lulus SD & 44 & 88 & 41 & 82 \\
2. & SD & 6 & 12 & 9 & 18 \\
\hline & Jumlah & 50 & 100 & 50 & 100 \\
\hline
\end{tabular}

Berdasarkan tabel 1. diketahui yaitu sebanyak 44 responden (88\%), bahwa pendidikan orang tua terbanyak untuk ibu dan 41 responden $(82 \%)$ adalah tidak lulus sekolah dasar (SD) untuk bapak.

Tabel 2. Tingkat Pendidikan Responden

\begin{tabular}{|c|c|c|c|}
\hline No & Pendidikan & Jumlah & $\%$ \\
\hline 1 & Tidak Lulus SD & 21 & 42 \\
\hline 2 & SD & 14 & 28 \\
\hline 3 & SMP & 12 & 24 \\
\hline 4 & SMA & 3 & 6 \\
\hline & Jumlah & 50 & 100 \\
\hline
\end{tabular}

Berdasarkan Tabel 2, diketahui bahwa pendidikan remaja terbanyak adalah tidak lulus sekolah dasar (SD) yaitu sebanyak 21 responden (42\%), dan paling sedikit lulus SMA, yaitu sebanyak 3 responden $(6 \%)$.

\section{B. Variabel Ekonomi}

Berdasarkan penelitian yang telah dilakukan, maka didapatkan hasil ekonomi keluarga responden sebelum menikah pada Tabel. 3 dan pekerjaan orang tua responden pada Tabel. 4 sebagai berikut:

Tabel 3. Ekonomi Keluarga

\begin{tabular}{clcc}
\hline No & \multicolumn{1}{c}{ Ekonomi } & Jumlah & \% \\
\hline 1 & Rendah & 26 & 52 \\
2 & Menengah & 18 & 36 \\
3 & Tinggi & 6 & 12 \\
\hline \multicolumn{2}{c}{ Jumlah } & 50 & 100 \\
\hline
\end{tabular}


Berdasarkan Tabel 3. diketahui bahwa ekonomi keluarga remaja sebelum menikah terbanyak yaitu ekonomi rendah sebanyak 26 responden (52\%), dan paling sedikit ekonomi tinggi sebanyak 6 responden (12\%).

Tabel 4. Pekerjaan Orang Tua

\begin{tabular}{clcc}
\hline No & \multicolumn{1}{c}{ Pekerjaan } & Jumlah & \% \\
\hline 1 & BuruhTani & 23 & 46 \\
2 & Petani Sendiri & 13 & 26 \\
3 & Nelayan & 8 & 16 \\
4 & Buruh Bangunan & 2 & 4 \\
5 & Pedagang & 2 & 4 \\
6 & Swasta Honorer & 2 & 4 \\
\hline & Jumlah & 50 & 100 \\
\hline
\end{tabular}

Berdasarkan Tabel 4. diketahui bahwa pekerjaan orang tua dari remaja sebelum menikah terbanyak yaitu buruh tani sebanyak 23 responden $(46 \%)$, dan paling sedikit swasta (honorer) sebanyak 2 responden (4\%).

\section{Variabel Sikap Remaja untuk Memutuskan Menikah di Usia Muda}

Variabel sikap remaja untuk memutuskan menikah di usia muda diperoleh dari 14 pertanyaan angket sikap remaja tentang marriage di usia muda. Berdasarkan skor jawaban angket, selanjutnya dilakukan kategorisasi sikap remaja untuk memutuskan marriage di usia muda dalam empat kategori dengan kriteria sebagai berikut: Sangat setuju, setuju, tidak setuju, sangat tidak setuju. Berdasarkan kriteria tersebut, semakin baik jawaban atau persepsi remaja terhadap kerugian yang ditimbulkan marriage di usia muda, maka semakin tidak setuju terhadap keputusan marriage di usia muda. Selanjutnya deskripsi daripada sikap remaja untuk memutuskan marriage di usia muda ditampilkan pada tabel 5 sebagai berikut:

Tabel 5. Sikap Remaja untuk Memutusan Menikah di Usia Muda

\begin{tabular}{clcc}
\hline No & \multicolumn{1}{c}{ Pendidikan } & Jumlah & \% \\
\hline 1 & Sangat Setuju & 0 & 0 \\
2 & Setuju & 8 & 16 \\
3 & Tidak setuju & 39 & 78 \\
4 & Sangat tidak setuju & 3 & 6 \\
\hline \multicolumn{2}{r}{ Jumlah } & 50 & 100 \\
\hline
\end{tabular}


Berdasarkan Tabel 5. diketahui bahwa sebagian besar remaja tidak setuju terhadap pernikahan di usia muda yaitu sebanyak 39 responden (78\%), dan yang paling sedikit yang sangat tidak setuju sebanyak 3 responden $(6 \%)$.

\section{Uji Normalitas}

Uji normalitas digunakan untuk mengetahui apakah data yang diper- oleh memiliki sebaran data yang normal. Normalitas data diuji menggunakan uji Kolmogorov-Smirnov. Kriteria uji adalah jika nilai p-value lebih besar dari 0,05, maka data telah memenuhi asumsi kenormalan. Pengujian normalitas kedua data penelitian adalah sebagai berikut.

Tabel 6. Hasil Uji Normalitas

\begin{tabular}{lcccc}
\hline \multicolumn{1}{c}{ Variabel } & $\boldsymbol{K S}$ & $\boldsymbol{p v}$ & Sig. & Ket \\
\hline Pendidikan & 1,818 & 0,003 & $\mathrm{P}<0,05$ & Tidak normal \\
Ekonomi & 2,287 & 0,000 & $\mathrm{P}<0,05$ & Tidak normal \\
Keputusan & 3,009 & 0,000 & $\mathrm{P}<0,05$ & Tidak normal \\
\hline
\end{tabular}

Hasil pengujian terhadap data sikap remaja untuk memutuskan marriage di usia muda menggunakan bantuan program SPSS for Windows diperoleh nilai probabiliats ( $p$-value) sebesar 0,000. Nilai probabilitas tersebut signifikan pada tingkat signifikansi 5\% $(p<0,05)$, sehingga disimpulkan sebaran data variabel tersebut tidak normal. Ketidaknormalan data mengakibatkan pengujian hipotesis penelitian dilakukan menggunakan analisis non parametrik, yaitu uji korelasi Rank Spearman.

\section{E. Analisis Data}

Penelitian ini bertujuan mengetahui hubungan tingkat pendidikan dan tingkat ekonomi dengan sikap remaja untuk memutuskan menikah di usia muda pada remaja di Desa Prapag Kidul Kecamatan Losari Kabupaten Brebes. Hipotesis penelitian adalah "ada hubungan antara tingkat pendidikan dan tingkat ekonomi dengan sikap remaja untuk memutuskan marriage di usia muda". Pengujian hipotesis tersebut menggunakan alat analisis data uji Rank Spearman atau Spearman Rho. Data penelitian berupa tingkat pendidikan, tingkat ekonomi keluarga dan sikap remaja untuk memutuskan marriage di usia muda, yang selanjutnya diuji menggunakan bantuan program SPSS for Windows. Analisis data menggunakan taraf kepercayaan (signifikansi) sebesar $5 \%$ atau 0,05 . Setelah diketahui nilai $r_{s}$ dilanjutkan dengan uji signifikansi uji t. Hasil analisis data selengkapnya adalah sebagai berikut: 
Tabel 7. Hasil Uji Rank Spearman dan Uji t

\begin{tabular}{lllllll}
\hline & Variabel & \multicolumn{1}{c}{$\boldsymbol{r}_{s}$} & $\mathbf{t}_{\text {hit }}$ & $\boldsymbol{t}_{\text {tab }}$ & Ket \\
\hline \multicolumn{1}{c}{ Bebas } & \multicolumn{1}{c}{ Terikat } & 0,419 & 2,88 & 2,021 & Signifikan \\
$\begin{array}{l}\text { Tingkat } \\
\text { pendidikan } \\
\text { Ekonomi }\end{array}$ & $\begin{array}{l}\text { Keputusan menikah } \\
\text { di usia muda }\end{array}$ & $\begin{array}{l}\text { Keputusan menikah } \\
\text { di usia muda }\end{array}$ & 0,308 & 2,11 & 2,021 & Signifikan \\
\hline
\end{tabular}

Selanjutnya hasil pengujian Rank Spearman dan uji t selengkapnya dijelaskan sebagai berikut:

\section{Hubungan pendidikan dengan sikap remaja untuk memutuskan menikah di usia muda}

Tabel 8. Hubungan Pendidikan dengan Sikap Remaja untuk Memutuskan Menikah di Usia Muda

\begin{tabular}{lccc}
\hline \multirow{2}{*}{ Pendidikan } & \multicolumn{3}{c}{$\begin{array}{c}\text { Sikap remaja untuk memutuskan menikah } \\
\text { di usia muda }\end{array}$} \\
\cline { 2 - 4 } & S & TS & STS \\
\hline Tidak Lulus SD & 5 & 16 & 0 \\
SD/MI & 3 & 11 & 0 \\
SMP/Mts & 0 & 12 & 0 \\
SMA/Aliyah & 0 & 0 & 3 \\
\hline Total & 8 & 39 & 3 \\
\hline
\end{tabular}

Tabel 8. menunjukkan bahwa terdapat kecenderungan bahwa semakin tinggi tingkat pendidikan remaja, maka semakin mereka tidak menyetujui keputusan menikah di usia muda.

Hasil perhitungan uji Spearman Rho menggunakan program SPSS for Windows sebagaimana nampak pada tabel 7 , didapatkan nilai $t_{\text {hitung }}$ sebesar
Hubungan pendidikan dengan keputusan marriage di usia muda ditampilkan dalam tabulasi silang (crosstab) sebagai berikut: 
nilai koefisien Rank Spearman $\left(\mathrm{rho}_{\mathrm{x} 1 \mathrm{y}}\right)$ sebesar 0,419, dan berdasarkan kriteria korelasi dari Sugiono (2005) hubungan antara tingkat pendidikan dan sikap remaja untuk memutuskan marriage di usia muda memiliki hubungan yang sedang yaitu antara 0,400 - 0,599.

\section{Hubungan ekonomi dengan sikap remaja untuk memutuskan menikah di usia muda.}

Hubungan ekonomi dengan sikap remaja untuk memutuskan marriage di usia muda ditampilkan dalam tabulasi silang (crosstab) sebagai berikut:

Tabel 9. Hubungan Ekonomi dengan Sikap Remaja untuk Memutuskan Menikah di Usia Muda

\begin{tabular}{lccc}
\hline \multirow{2}{*}{\multicolumn{1}{c}{ Ekonomi }} & \multicolumn{3}{c}{$\begin{array}{c}\text { Sikap remaja untuk memutuskan marriage } \\
\text { di usia muda }\end{array}$} \\
\cline { 2 - 4 } & S & TS & STS \\
\hline Rendah & 5 & 21 & 0 \\
Menengah & 3 & 15 & 0 \\
Tinggi & 0 & 3 & 3 \\
\hline Total & 8 & 39 & 3 \\
\hline
\end{tabular}

Tabel 10. menunjukkan bahwa terdapat kecenderungan bahwa semakin tinggi tingkat ekonomi keluarga, maka semakin mereka tidak menyetujui keputusan marriage di usia muda.

Hasil perhitungan uji Spearman Rho menggunakan program SPSS for Windows sebagaimana nampak pada tabel 7 di atas, diperoleh nilai $t_{\text {hitung }}$ sebesar 2,11 dan $p$-value sebesar 0,030. Karena nilai $t_{\text {hitung }}$ lebih besar dari $t_{\text {tabel }}$ = 2,021 dan $p$-value lebih kecil dari 0,05, maka keputusan analisis adalah $\mathrm{H}_{0}$ ditolak atau $\mathrm{H}_{\mathrm{a}}$ diterima yang berarti terdapat hubungan tingkat ekonomi dengan sikap remaja untuk memutuskan marriage di usia muda pada remaja di desa Prapag Kidul Kecamatan Losari Kabupaten Brebes. Nilai koe- fisien Rank Spearman $\left(\mathrm{rho}_{\mathrm{x} 2 \mathrm{y}}\right.$ ) sebesar 0,308, dan berdasarkan kriteria korelasi dari Sugiono (2005) hubungan antara tingkat ekonomi dan sikap remaja untuk memutuskan marriage di usia muda memiliki hubungan yang rendah yaitu antara 0,200 - 0,399.

Hasil penelitian ini menunjukkan tingkat pendidikan remaja relatif rendah, paling banyak tidak lulus SD sebanyak $42 \%$, dan paling sedikit lulus SMA sebanyak 6\%. Diketahui juga pendidikan orang tua dari remaja adalah: untuk bapak, paling banyak tidak lulus SD sebanyak $82 \%$, demikian juga dengan ibu paling banyak tidak lulus SD sebanyak $88 \%$. Dari hasil ini dapat disimpulkan bahwa pendidikan orang tua remaja juga rendah. 
Berdasarkan pekerjaan, ekonomi keluarga yang mempunyai remaja yang menikah di usia muda diketahui paling banyak tingkat ekonominya rendah, yaitu sebanyak 52\%. Dengan demikian mayoritas ekonomi keluarga yang mempunyai remaja yang menikah di usia muda yaitu berekonomi rendah. Dari hasil penelitian diketahui bahwa orang tua responden paling banyak memiliki pekerjaan sebagai buruh tani, yaitu sebanyak $46 \%$ dan paling sedikit bekerja swasta honorer sebanyak $4 \%$.

\section{Sikap remaja terkait keputusan menikah di usia muda}

Ditinjau dari sikap terhadap pernikahan di usia muda, hasil penelitian menunjukan bahwa remaja yang marriage di usia muda memiliki sikap yang baik karena sebagian besar dari mereka tidak setuju mengenai marriage diusia muda $78 \%$, sangat tidak setuju $6 \%$, setuju $16 \%$ dan sikap sangat setuju $0 \%$. Walaupun remaja pada kenyataannya telah marriage di usia muda tetapi pada dasarnya mereka tidak mendukung pernikahan di usia muda. Salah satu faktor yang mempengaruhi pembentukan sikap adalah pengaruh orang lain yang dianggap penting. Menurut Azwar (2000), diantara orang yang biasanya dianggap penting oleh individu adalah orang tua, individu cenderung untuk memiliki sikap yang kompermis atau searah dengan sikap orang yang dianggap penting tersebut. Jadi, sesuai dengan teori diatas kebanyakan remaja sikapnya terhadap keputusan marriage di usia muda terbentuk karena pengaruh orang tua. Dikuatkan juga oleh pendapat Yulmia (2008) yang menyatakan bahwa dalam kehidupan seharihari anak tidak saja diharapkan untuk menghormati orangtua mereka, tetapi juga membantu ekonomi keluarganya apabila dibutuhkan. Salah satu bentuk kepatuhan anak yang menyebabkan seorang anak perempuan rentan terhadap perdagangan dan eksploitasi seksual adalah dinikahkan pada usia dini dengan alasan supaya anak dapat hidup lebih baik dan terhindar dari pergaulan bebas remaja, seringkali orang tua menjerumuskan anaknya dengan marriagekan anaknya pada usia dini dengan lelaki pilihan orang tua. Karena adanya kekhawatiran terhadap keperawanan anak perempuan, mengingat kehormatan keluarga berhubungan erat dengan keperawanan dan kesucian seorang perempuan. Adat marriagekan anak dalam usia dini mempunyai tingkat kegagalan yang sangat tinggi.

\section{Hubungan faktor pendidikan dengan sikap remaja untuk memutuskan menikah di usia muda di Desa Prapag Kidul kecamatan Losari Kabupaten Brebes.}

Berdasarkan hasil penelitian didapatkan adanya hubungan antara faktor pendidikan dengan keputusan 
remaja untuk marriage diusia muda. Banyaknya remaja yang menikah di usia muda berpendidikan tidak lulus SD dan hanya SD dari pada remaja yang berpenddikan SMP atau SMA membuktikan bahwa semakin tinggi penddikan remaja maka semakin kecil kecenderungan untuk memutuskan menikah di usia muda. Faktor pendidikan disini mempengaruhi pola pikir para remaja. Hal ini sesuai dengan penelitian Institut Guttmacher (1998), perkawinan awal pada wanita yang mempunyai pengetahuan/pendidikan di bawah pendidikan dasar secara kasar adalah tiga kali lipat dari pada wanita yang sekurangnya bersekolah selama 7 tahun, misalnya di Indonesia hasil survai menyebutkan bahwa di Indonesia pada tahun 1994 wanita usia 20-24 yang marriage atau hidup bersama sebelum usia 18 dan bersekolah kurang dari 7 tahun sebanyak 49\% sedangkan wanita usia 20-24 yang marriage atau hidup bersama sebelum usia 18 dan bersekolah 7 tahun atau lebih sebanyak $10 \%$.

Pendidikan yang rendah mendukung remaja untuk cenderung memilih marriage di usia muda, karena remaja yang berpendidikan rendah akan mempunyai pengetahuan sedikit dari masa belajarnya di sekolah sehingga informasi mengenai kesehatan reproduksi, informasi persiapan untuk marriage (fisik, psikis, finansial, emosional) dan pengetahuan yang lain kurang sehingga remaja marriage muda tanpa memikirkan kedepannya.. Ketika pendidikan terbatas, maka tidak banyak berbicara dalam pengambilan keputusan sehingga para remaja menuruti saja apa yang diinginkan orangtua yaitu anaknya segera marriage. Sesuai dengan penelitian Guttmacher Institut (1998), yang menyatakan bahwa para perempuan yang marriage pada usia muda sering tidak bisa banyak berbicara dalam pengambilan keputusan mengenai kesuburan dan kesempatan yang terbatas untuk mengenyam pendidikan atau kesempatan kerja. Menurut Budiyono (2008) mengatakan bahwa remaja yang berasal dari latar belakang keluarga yang lebih mampu akan memiliki kesempatan untuk mengakses kepada pendidikan yang lebih baik. Pendidikan yang lebih baik karena sekolah yang berprestasi atau bisa juga dalam pengertian ke jenjang pendidikan lebih tinggi. Dengan pendidikan yang tinggi mereka memiliki kemungkinan terpapar kepada informasi yang lebih benar. Remaja yang berasal dari kalangan keluarga yang berada pada kuantil kekayaan teratas memiliki kemungkinan 0.616 kali untuk berperilaku beresiko dibandingkan remaja yang keluarganya berada pada kuantil kekayaan terbawah. Menurut MaryBeth (2006), Pendidikan yang terbatas (rendah) adalah salah satu faktor penyebab terjadinya kondisi ibu muda, ibu-ibu kelompok ini umumnya harus berjuang secara ekonomi dan anak- 
anak mereka umumnya mengulang perilaku cara hidup mereka yang berada dalam kemiskinan.

Di Desa Prapag Kidul, ketika remaja sudah putus sekolah maka cenderung hanya tinggal dirumah saja dan menunggu datangnya pria yang melamar, karena di desa tersebut ketika remaja sudah mau mendekati usia 20 perempuan takut di katakan sebagai perawan tua. Hal ini sesuai dengan hasil penelitaan Subiyantoro (2002) Bahwa anggapan remaja di desa lebih memungkinkan untuk marriage di usia muda karena di desa perempuan dalam pernikahan didasarkan pada mitos "Perawan Tua" persoalan mendasar dari seorang anak perempuan, ketika dia telah memasuki usia dewasa, banyak orang tua menginginkan anaknya untuk tidak menjadi perawan tua. Menjadi perawan tua bagi kebanyakan masyarakat dianggap sebagai bentuk kekurangan yang terjadi pada diri perempuan. Di desa Prapag Kidul remaja banyak yang mengikuti pendidikan orang tuanya ini terbukti dari keduanya yang berpendidikan sama-sama rendah atau bahkan orang tua yang ingin anaknya menempuh pendidikan seperti mereka biar cepat kerja dan membantunya, remaja di desa prapag kidul juga kebanyakan mengikuti pekerjaan orang tuanya. Mereka berhenti sekolah karena ingin membantu keluarganya mencari uang dan mengurangi biaya hidup keluarga. Hal ini sesuai dengan pendapat
Hisyam (2005) di desa Kemojan sebelum 2001 nyaris tidak ada yang melanjutkan ke jenjang SMP/MTs setelah lulus SD karena jika sudah lulus SD yang putra ikut mancing bapaknya sedangkan yang putri menunggu lamaran pernikahan. Jadi masih banyak masyarakat yang tetap berpola pikir lama yaitu mementingkan marriage daripada bersekolah.

\section{Hubungan faktor ekonomi dengan sikap remaja untuk memutuskan marriage diusia muda di desa Prapag Kidul kecamatan Losari kabupaten Brebes.}

Berdasarkan hasil penelitian didapatkan adanya hubungan antara faktor ekonomi dengan sikap remaja untuk memutuskan marriage diusia muda. Penelitian ini sesuai dengan beberapa pendapat dan teori-teori diantaranya; Hisyam (2005), menyebutkan bahwa faktor geografis dan ekonomis, serta pola pikir masyarakat lokal berpengaruh besar pada banyaknya pernikahan dini.

Berdasarkan hasil penelitian menunjukan bahwa mayoritas ekonomi keluarga yang mempunyai remaja marriage di usia muda adalah berekonomi rendah. Jadi ekonomi yang rendah cenderung membuat keluarga menyegerakan anak remajanya untuk marriage. Ini sesuai dengan pendapat Hertog (2006) yang menyatakan bahwa pernikahan dini umumnya terjadi di masyarakat pedesaan, terutama go- 
longan ekonomi menengah ke bawah. Karena hal itu lebih merupakan bentuk solusi pembagian tanggung jawab dari keluarga perempuan pada suami. Dengan marriage, lepaslah tanggung jawab orang tua untuk menafkahi anaknya. Sementara di masyarakat perkotaan, pernikahan dini umumnya terjadi karena "kecelakaan" akibat salah pergaulan.

Hasil penelitian menunjukan bahwa mayoritas pekerjaan orang tua dari remaja sebelum remaja marriage adalah sebagai buruh tani. Buruh tani adalah pekerjaan yang penghasilannya tidak menentu dan pekerjaan itu ada pada musim-musim tertentu seperti musim penghujan, ketika musim kemarau para buruh tani biasanya banyak yang menganggur atau mencari pekerjaan lainnya untuk memenuhi kebutuhan hidupnya. Para buruh tani cenderung marriagekan anak remajanya untuk meringankan beban keluarga, diharapkan anaknya setelah marriage ekonominya lebih baik sehingga dapat membantu keluarga sebelumnya, dengan marriagekan anaknya orang tua melepaskan tanggung jawab anaknya ke suaminya. Hal ini sesuai dengan pendapat Erkus (2005) bahwa faktor budaya setempat dan problematika ekonomi memang menjadi penyebab terjadinya pernikahan muda, seperti sebuah ungkapan polos dari orang tua yang berpikir bahwa jika anak gadisnya cepat marriage, tidak akan ada lagi banyak persoalan yang akan dihadapi. Seorang ibu menganggap jika anak gadisnya telah ada yang melamar dan mengajak marriage, maka diharapkan anak gadisnya akan mandiri dan tidak lagi tergantung kepada orang tua, karena sudah ada suami yang siap menafkahi. Walaupun usia anak perempuan belum mencapai kematangan, baik secara fisik maupun mental. Remaja yang sudah dapat mencari uang sendiri, mempunyai pekerjaan, mereka cenderung akan secepatnya marriage walau usianya masih terlalu muda, karena tidak ada lagi yang mereka kerjakan.

\section{KESIMPULAN DAN SARAN}

\section{A. Kesimpulan}

Hasil penelitian dapat disimpulkan sebagai berikut: tngkat pendidikan remaja yang marriage diusia muda mayoritas berpendidikan rendah, yaitu SD ke bawah, tingkat pendidikan orang tua remaja yang menikah diusia muda mayoritas berpendidikan rendah, yaitu SD kebawah, tingkat ekonomi keluarga dari remaja sebelum menikah di Desa Prapag Kidul rendah, ada pengaruh antara faktor pendidikan dengan sikap remaja untuk memutuskan menikah di usia muda di Desa Prapag Kidul Kecamatan Losari Kabupaten Brebes ( $\mathrm{P}=$ $0,002, a=0,05$ ) serta ada pengaruh antara faktor ekonomi dengan sikap remaja untuk memutuskan marriage di usia muda di Desa Prapag Kidul Kecamatan Losari Kabupaten Brebes $(\mathrm{P}=0,030$, = $0,05)$. 


\section{B. Saran}

Perlu meningkatkan kesadaran masyarakat untuk ikut berpartisipasi mencegah supaya tidak terjadi pernikahan remaja diusia muda di lingkungan mereka dengan menyadari arti penting pendidikan bagi anakanaknya dan tidak memaksakan anak untuk menikah diusia muda serta bagi instansi terkait supaya ikut mendukung penurunan angka kematian pada ibu melahirkan dan bayi dengan berat badan lahir rendah (BBLR) melalui penyuluhan tentang resiko kesehatan terkait menikah di usia muda, penyuluhan tentang kesehatan reproduksi remaja.

\section{DAFTAR PUSTAKA}

Arikunto, 2006. Prosedur Penelitian Suatu Pendekatan Praktek Edisi Revisi VI. Rineka Cipta : Jakarta.

Azwar, S, 2000. Sikap Manusia, Teori dan Pengukurannya. Pustaka Pelajar Jogja Offset: Yogyakarta.

Budiyono, 2008. Remaja Beresiko Siapakah Mereka? http:// tabloidjubi. wordpress. Com / 2008/ 02/06.remaja-dan - perilaku - beresiko - siapakah - mereka/ Diakses : 6 Februari 2008.

Guttmacher Institute, 1998. Memasuki Sebuah Dunia Baru Kehidupan Seksual dan Reproduksi Perempuan Muda. http// www. Agi-usa. Org/shopper/. Diakses 3 Januari 2008.

Hertog, 2006. Plus Minus Nikah Muda. http://www.mail_archive.com/sarikata@ yahoo groups. com. Diakses 8 Februari 2006.

Erkus, 2005. Wanita Jabar, Ibaratnya Ditoel Saja Hamil. www.pikiran rakyat.com/cetak/ hikmah. Diakses 3 Januari 2008.

Hisyam, 2005. Banyak Yang Nikah Dini. http :/ / www. Suara merdeka. Com/harian/ 0509/21/mur09.htm. Diakses 3 januari 2008.

Mary-Beth, 2006. Sejuta Bayi Dilahirkan Ibu Muda Meninggal Tiap Tahun. www . perempuan .com. Diakses 3 januari 2008.

Nugroho, 2006. Pernikahan Dini Tingkatkan Resiko Kanker Servik. www. dinkes kota semarang go. Id $/$ index .Php ? ophon $=$ com - content $\&$ task $=$ view \& id $=$ 74 \& item id = 35 -15k. Diakses 8 Februari 2007. 
Sugiono, 2005. Statistik Untuk Penelitian. Penerbit CV ALFA BETA Bandung: Bandung.

Suryadi, 2005. Tinggi, Angka Kawin Muda di Jabar. www. pikiran-rakyat. com/ cetak/ 2005/ 0605/05/hikmah/lainnya03.htm-17k. Diakses 13 September 2007.

Subiyantoro, 2002. Perempuan dan Perkawinan Sebuah Pertaruhan Eksistensi Diri. Jurnal Perempuan Edisi 22. Hal 7-12.

Teguh, 2007. 59,37\% Perempuan Nikah Dini. www. Bapeda_Jabar. go.id/ bapeda_design/ dokumen_informasi.php? Diakses 13 September 2007.

Wiraswasti, Lina , 2005. Kesiapan Psikososio-Spiritual Pasangan Marriage Muda, KTIS1 Psikologi tidak diterbitkan, Universitas Muhammadiyah Surakarta.

Yulmia, 2008. Menggugat Praktik Trafficking. http://satudunia.One world.net/ article/ view / 157069/ 1 / 512. Diakses 8 Februari 2008. 